ROCZNIKI PEDAGOGICZNE

Tom 13(49), numer $4-2021$

DOI: http://doi.org/10.18290/rped21134.4

\title{
AXIOLOGICAL FOUNDATIONS OF SOCIAL PEDAGOGY: SEARCH AREAS
}

\section{INTRODUCTION}

The issue of values in social sciences, including pedagogy, is one of the crucial ones: one could even venture saying that it is a fundamental one. This is even more so as such sciences usually make more or less clear references to practice and in consequence have such structural - teleologic [practical and praxeological] translation of the adopted solutions (for example, this is the case in social politics, economics, social pedagogy or sociology of education). In this sense, they are always demanding a specific normative localisation, i.e. a reference to specific models and templates.

This mechanism is very clear in reference to the process of education as the basic procedure to which pedagogy refers and around which its specific concepts and theories have evolved. In this sense, education entails indication of directions of impact: delivery of specific stimulating content that builds the most optimum development of man in all spheres of his life, also in the sphere of behaviour and interpersonal relations. Bearing such fundamental significance and role of values in the process of education in mind, one may venture saying that they form the basis of this process.

Due to the fact that the process of education is quite complex, has various levels and realms, the issue of values may be and is diversely investigated on the basis of such process. Every pedagogical sub-discipline does it in its own specific manner: investigating, determining and defining areas of its searches in this respect. This is also the case with social pedagogy.

Prof. dr hab. Mariusz Cichosz - Wydział Pedagogiki Uniwersytetu Kazimierza Wielkiego w Bydgoszczy; adres do korespondencji: ul. Chodkiewicza 30, 85-064 Bydgoszcz; e-mail: acichosz@ o2.pl; ORCID: https://orcid.org/0000-0002-1177-7793 
The purpose of this article is to analyze and show what the principle of the common good is - especially developed according to Christian thought. Also, what is its place in pedagogy - especially in social pedagogy, and to what challenges it leads today.

\section{VALUES IN SOCIAL PEDAGOGY: SEARCH AREAS}

The basic area indicated as fundamental for social pedagogy, characterising it and specific for it - in consequence also defining this discipline in this perspective is the area of relations that occur between man and the society (the environment). Anna Przecławska and Wiesław Theisse, some of the leading modern representatives of this pedagogical discipline, wrote about in the following manner: "... this discipline deals with the theory of environmental determinants of education and man's development and theory and practice of shaping the environment. Social and cultural work which frequently occurs in this context is treated as a form of transformation of the environment [...]. Social educators have always agreed that a causative factor of the change and construction of the reality is own capacity of the environment - social (human) forces, understood as the dynamic intended to "make things better" (Przecławska, 1993, p. 9).

Therefore, the axiological themes tackled in the area of social pedagogy are consistently reduced to such source-based, ontological and structural approach in the subjective sense (designated research areas). It is a subject matter clearly linked to the issue of relation that occurs between an individual man and the environment/ society (Cichosz, 2014).

This relation is also described axiologically, and this is what it requires as a teleological type relation with its necessary translation into practice - where we ask about the values that have to be realised. ${ }^{1}$ The concept of man adopted here and the concept of the sole structure of social life (the society) are to be

\footnotetext{
${ }^{1}$ The issue of values in pedagogy has been discussed relatively rarely. In this case, it is difficult to speak about ontological or epistemological models that have been developed and that became fixed. The works of first social educators, as well as the ones active in the school of H. Radlińska which is the humanistic and clearly anthropological current of this discipline, are more pronounced in this respect. On the other hand, the currently dominant tradition of social pedagogy inspired by Marxism that is clearly functionally interpreted, more in the spirit of systemic sociology and social relations comprehended in a determinist manner, has not expanded the sphere of values and such axiological bases of this discipline. The issue is also tackled by the author of this paper in other studies which are referenced here, cf. M. Cichosz, Aksjologiczne inspiracje w pracy socjalnej kontekst współczesnych przemian cywilizacyjnych, in: K. Marzec-Holka (ed.), Pomoc społeczna - praca socjalna. Teoria i praktyka, vol. 1, Bydgoszcz 2003, pp. 81-91, as well as: O strukturze
} 
searched for and defined in this complex relational context as the key elements of this relation. Thus, the subject matter of values was and is connected in social pedagogy; it is hidden (contained) in this relation and it refers to it. In this sense, it is difficult to state unequivocally that, for example, the subjective character of social education comprises specifically understood subjectivity of man, an individual, including his/ her capacity for creative social actions or cultural activity. These activities are always "entangled" or are the product of broader social and environmental relations - mechanisms of social life that influence them. In turn, they may be diversely understood: they do not necessarily have to overlap and do not have to imply (in the sense of epistemological, ontological and axiological identity) man's subjective role. Social pedagogy may be an example of it: most often, social pedagogy understood functionally and deterministically (also nowadays) as far as the course of social life is concerned - with simultaneous dominant declaratively personalistic and humanist comprehension of man. Even though it is simultaneously necessary to remember that personalism and humanism may have diverse interpretations, also opposing, which may be found both in extremely individualistic and not deterministic concepts, as well as it is possible to accept behavioural/ instrumental justifications.

Therefore, the sole principles of pedagogical impacts - adopted in social pedagogy, the principles regulating social life - clearly interpreted axiologically and with such axiological "nature" as, for example, the principle of the common good, the principle of social justice, subsidiarity, support but also social capital, are also the products of comprehending social life and comprehending man - an active participant of social life - his/ her subjectivity. ${ }^{2}$

Additionally, every type of pedagogy, including social pedagogy, carries an immanent, structurally incorporated imperative of action - the necessity of carrying out specific educational practice, which was mentioned before. This is the third interpretation area for the issue of values and, at the same time, another realm of concepts adopted in this respect, which obviously remain in a close relationship with the concept of man, as well as the concept of social relations (social life). ${ }^{3}$

ontologicznej i aksjologicznej pedagogiki społecznej - w poszukiwaniu wartości, Wychowanie na co dzień, (2013), 3 (234), 12-15.

${ }^{2}$ Cf. B. Smolińska-Theiss, Od chrześcijańskiego miłosierdzia do liberalnej demokracji, Problemy Opiekuńczo-Wychowawcze (1994), 5. A wide interpretative spectrum in such axiological reading of social life, also from the point of view of understanding subjectivity, can be found, e.g., in the published social pedagogy works which are devoted to the issue of "social capital" cf. K. MarzecHolka (ed.). Kapitat społeczny a nierówności. Kumulacja i redystrybucja. Bydgoszcz 2005. Also M.Theiss. Krewni, znajomi, obywatele. Kapitat społeczny a lokalna polityka społeczna. Torun 2007.

${ }^{3}$ What is more, comprehensive and separate concepts of social pedagogy have been worked out, where the "interpretation" basis (on the ontological, epistemological and axiological level) is 
Therefore, the task of identifying social pedagogy with respect to the values present in it is quite complex and potentially quite hard to determine unequivocally. Various decisions and adopted solutions exist in this respect.

\section{COMMON GOOD: AXIOLOGICAL REALM OF SOCIAL EDUCATION}

One of the aforementioned spheres of functioning of values in pedagogy - also social pedagogy - are principles which underlie the regulation of social life. One of such principles which is traditionally indicated in pedagogy is the principle of the common good.

\section{- Comprehension of term: Christian inspirations}

The issue of the common good in the discussions pertaining to social life has emerged a long time ago. The beginnings of this idea can be found in Plato's works. In the Roman legislation, the issue of the common good was called the society's welfare. Christianity has dealt with the issue of the common good since the very beginning. St. Augustine expressed it with the use of "peace and wellordered concord" formula (Krucina, 1985). However, the issue was discussed and presented most comprehensively by St. Thomas Aquinas (Majka, 1982, cf. Kondziela, 1972). St. Thomas showed the common good in the form of, or rather with the use of the model of the world: "[...] creatures, based on partial existence and specific places in a proportionally arranged cosmos, participate in the Supreme Good (God) which is the ultimate common good (Summun bonum communie) [...]" (Krucina, 1985, p. 1379). St. Thomas also believed that "[...] the order of the universe and analogously comprehended perfection of the universe, with the participation of the good of individual creatures and also the social order, which connects actions of people striving for happiness and perfection of the human nature, reaching greater fullness along with the improvement of the society [...]" (ibidem, p. 1379).

In such approach, the common good was understood as a social moral principle which has been applicable beyond the specific conditions of time and place. In this sense, it is possible to clearly distinguish two levels of the common good: ontological and anthropological. In the ontological sense, the common goods is to be understood transcendentally and it is eventually God and the order of

the overriding category of "action" cf. E. Marynowicz-Hetka. Pedagogika spoleczna. Academic textbook, vol. I and II. Warszawa 2007. 
the cosmos, whereas in the anthropological sense it is the good of humanity or a specific community. ${ }^{4}$

Decisions pertaining to the idea of the common good made by St. Thomas Aquinas have set the direction for this issue for a number of years and even though it has been tackled in various periods of time, it returned with a great impetus at the turn of the $19^{\text {th }}$ and the $20^{\text {th }}$ century. Assuming, as the initial definition of the common good, the definition put forward by St. Thomas, it may be concluded that it relies on the fact that a man participates in the common good and - simultaneously - by participating in social life, co-creates the common good of these communities to which he belongs. On the other hand, a community is understood as a group of people, sensible and free creatures. It is the nature of people to create culture: economic, artistic, moral, etc. In this sense, a broadly understood culture has the axiological dimension of the common good, which cannot be comprehended without permanent values and moral standards.

\section{- Modern determinations}

Nowadays, there are various concepts of the common good and various approaches to this issue. It is possible to distinguish the individualistic, the collectivist and the personalistic approach (Kowalczyk, 1994, p. 238). In the individualistic and liberal approach, the category of the common good is overlooked or reduced exclusively to the sphere of material and economic values. Liberalism, emphasising and stressing the rights of individuals, reduces their social obligations, leading to the formation of antisocial stances. Moral values and standards, without which it is difficult to speak about the common good, are relativised here. In the collectivist concept, the common good plays a very important role. However, a dangerous transfer takes place here and thus the sense of the idea becomes warped. Namely, instead of the welfare of a person, the roles of social, economic and political structures are emphasised. Collectivism understood in this manner transforms into a totalitarian system, where human rights are limited and human dignity is often compromised. The third approach to the common good, namely the personalistic approach, assumes bi-polarity of the idea. Two constituent elements, internal and external, can be distinguished in the structure of the common good: "[...] an internal element of the common good has ontological and axiological nature; namely, such good is the integral development of the human person and a set of values that are necessary for it. The external element of the common good

\footnotetext{
${ }^{4}$ Deeper understanding of the idea of the common good in Thomist social philosophy and theology would require more thorough and more detailed analyses. Reference books emphasise that the works of St. Thomas of Aquinas feature as many as 343 texts where he tackles the issue of the common good, cf. J. Majka (1982), p. 155.
} 
has the socio-institutional profile; it is a set of structures, institutions, economic and social conditions indispensable for the realisation of the common good [...]" (Kowalczyk, 1994, p. 236; cf. Krąpiec, 1979, pp. 293-300). Therefore, it may be said that in this approach, the common good focuses on the person and these values which enable his/ her harmonious development. Therefore, the common good is the human person and values. Due to the fact that man as a social creature is fulfilled (he may develop) in such areas as economics, culture, ethics, religion, etc., the common good comprises economic, cultural, moral, ideological values etc. In the personalistic approach it is also stressed that the common good - if it is to remain such - must have certain features. Among such features, Jacques Maritain enumerates:

- the common good should be distributed, therefore its redistribution is possible and necessary;

- the common good should be the basis and should assume the existence of a social authority, which would take care of its realisation;

- the common good should be ethically just (Majka, 1982, p. 171).

The concepts of the common good quoted here may be assigned to two categories: instrumentalist/ institutionalist and essential (Krucina, 1985, p. 1380). In the instrumentalist and institutionalist concept, the society is required to offer assistance and contribute to the development and improvement of the individual - a person as a unique and independent creature. In the essential concept, man's development is determined not so much by the offered "instrumental assistance", as it has a subsidiary character, but the man's inborn orientation on good and his susceptibility with respect to the acquisition and accumulation of values. This inborn focus on good and its acquisition has not only an individual, but also a social character: we desire good and we strive for it not only on our own, but with others.

The modern discussions on the idea of the common good are primarily carried in the area of social philosophy and sociology. Philosophical directions that have a wealthy tradition of discussions on the common good are Thomism and Christian personalism. A number of analyses discussed today in ethics have their clear and unequivocal references to the common good. This issue is directly related to the problem of human rights, freedom and values.

\section{- In social pedagogy: challenges}

In social pedagogy, in particular in the traditions of Polish social pedagogy, the issue of the common good has its reference to such ideas as: the idea of social justice, the idea of subsidiarity, etc. These are social ideas that were clearly present in the concepts of the $19^{\text {th }}$ century social pedagogy, in particular the school of Helena Radlińska. These ideas are valid even today, in spite of the fact that the 
current civilisation and cultural changes require taking a slightly different look at the aforementioned ideas, and thus the idea of the common good, accounting for the modern socio-cultural context and the specific of the present changes. Nevertheless, it seems that the fact that it is impossible to fully comprehend and justify a man/ a person in reference to social life, without reference to the world of values, remains unchallenged here. On the other hand, this sole fact justifies organised, institutional aid for man that is offered in his development so that his dignity is respected and the right to development is fully guaranteed.

Therefore, pedagogy in general and social pedagogy in particular has a special task: social care for man's welfare, organisation of assistance in development, ensuring just growth in respect of man's nature, focused on the world of values to which the man is constantly heading and which he carries within himself.

The principle of the common good in relation to specific challenges - important for educational practice, can translate into the following activities:

- establishing specific educational institutions - care, social and animational related to the dissemination of culture;

- through educational activities finding and strengthening social forces, in the fields of: care, help and social and cultural animation;

- stimulating local identity - referring in this regard to the existing traditions of a given place;

- finding and developing local cultural and social resources;

- in terms of individual influences, promoting pro-social attitudes as well as social involvement and participation.

\section{RECAPITULATION}

The issue of values for social sciences and thus for pedagogy seems to be an important and fundamental one. All sciences that are focused on man and his relations with the world, in particular relations with another person and other people obviously refer to and are embedded in the world of standards and models, in the world of expectations and desires, as well as spiritual experiences and such references: this is the world of values. In these sciences, they are subjected to a rational review and cognitive penetration. In this respect, this is the important task of getting to know the already worked-out traditions, but also a challenge to listen carefully to the conditions and transformations of the modern times. 


\section{BIBLIOGRAPHY}

Cichosz, M. (2013). O strukturze ontologicznej i aksjologicznej pedagogiki społecznej - w poszukiwaniu wartości, Wychowanie na co dzień, 3 (234).

Cichosz, M. (2014). Pedagogika społeczna. Zarys problematyki. Kraków.

KowalczyK, S. (1994). Człowiek a społeczność. Lublin.

KrąPIEC, M.A. (1979). Ja - czlowiek. Zarys antropologii filozoficznej. Lublin.

Krucina, J. (1985). Dobro wspólne. In: Encyklopedia Katolicka. Vol. 3. Lublin.

MajKa, J. (1982). Filozofia społeczna. Wrocław.

Marzec-Holka, K. (2005) (ed.). Kapitał społeczny a nierówności. Kumulacja i redystrybucja, Bydgoszcz.

Marzec-Holka, K. (2003) (ed.) Pomoc społeczna - praca socjalna. Teoria i praktyka, vol. 1. Bydgoszcz.

MarzeC-HolKa, K. (2005) (ed.). Kapitat społeczny a nierówności. Kumulacja i redystrybucja. Bydgoszcz.

Marynowicz-HetKa, E. (2007). Pedagogika społeczna. Academic textbook, vol. I and II. Warszawa.

PrzeclawsKa, A., Theiss, W. (1993). Pedagogika społeczna: nowe zadania i szanse. In: A. Przecelawska (ed.). Pedagogika społeczna. Kręgi poszukiwań. Warszawa.

Theıss, B. (1994). Od chrześcijańskiego miłosierdzia do liberalnej demokracji. Problemy OpiekuńczoWychowawcze, 5.

TheIss, M. (2007). Krewni, znajomi, obywatele. Kapitat społeczny a lokalna polityka społeczna. Toruń.

\section{AXIOLOGICAL FOUNDATIONS OF SOCIAL PEDAGOGY: SEARCH AREAS}

\section{SUMMARY}

The issue of values is of key importance in social sciences and thus in pedagogy. The process of education is strongly embedded and makes references to such aspects as models, templates and standards. In turn, they are interpreted axiologically and always receive the axiological interpretation. Every pedagogical sub-discipline tackles this issue in a specific and aspect-related mode. For social pedagogy, apart from the traditional cognitive and interpretative areas, such as the adopted concepts of man and social life, the area and the subject matter of principles on the basis of which the social world should be/ could be transformed is also of great importance. One of such principles is the principle of the common good. One may ask: to which traditions does social pedagogy refer in this respect, how does it interpret this principle and what are the present-day challenges related to it?

Keywords: Education; environment; values; common good; personalism. 


\section{AKSJOLOGICZNE PODSTAWY PEDAGOGIKI SPOŁECZNEJ: WYSZUKIWANIE OBSZARÓW}

\section{Streszczenie}

Problematyka wartości jest problematyką kluczową w naukach społecznych, także w pedagogice. Proces wychowania bowiem mocno osadzony jest i odwołuje się m.in.; do takich zagadnień, jak; wzory, wzorce i normy. One zaś są interpretowane aksjologicznie i uzyskują zawsze właśnie taką aksjologiczną interpretację. Każda też z subdyscyplin pedagogicznych podejmuje to zagadnienie w sposób specyficzny i aspektywny. Dla pedagogiki społecznej obok już tradycyjnych obszarów poznawczych i interpretacyjnych w tym zakresie, jak przyjmowane koncepcje człowieka oraz życia społecznego ważny jest także obszar i problematyka zasad, w oparciu o które należy/można przekształcać - w procesie wychowania - świat społeczny. Jedną z nich jest zasada dobra wspólnego. Można postawić pytanie: do jakich tradycji nawiązuje w tym zakresie pedagogika społeczna, jak interpretuje tą zasadę oraz jakie są współczesne wyzwania z nią związane?

Słowa kluczowe: Wychowanie, środowisko, wartości, dobro wspólne, personalizm. 